\title{
Short Biographies
}

\section{Ayni, Mehmet Ali (1868-1945)}

\section{Dilek Sarmis}

Born in 1868 and graduated from the Ottoman Higher School of Administration, A. had to leave the career of high-ranking civil servant in 1913 and invested himself in academic life as dean of faculty and professor of history of philosophy; he notably was the first teacher of history of mystics (tasavvuf tarihi) at the republican faculty of theology from 1924 to 1933. He translated in 1933 the History of Religions by Denis Saurat, and after the closure of the Faculty of Theology, he became the holder of the first chair of History of religions of the short-lived Institute for research on Islam. Connected at different times in his life to scholarly orientalist milieu but also spiritualist and metapsychic networks, he combined an orthodox academic and intellectual career with spiritualist practices of communication with spirits. He may have been at the beginning of the 1900s head of a Muslim spirit group in contact with the Revue spirite and participated in mediumnic seances. In 1923, he enjoined the Sufi Society (Cemiyet-i Sufiye) to initiate contacts with European Theosophical societies. In 1926 he met the Danish anthroposophist Carl Vett, who proposed him to lead the Turkish branch of the Society of Metapsychic Studies. He maintained his interest in spiritualism and metapsychics until the end of his life, although he did not mention them in his academic works.

Besides his writings on history of philosophy, logic and morals, his academic and hagiographic works about the great saints of Islam and Sufism made A. an important figure of Turkish esotericism. In particular he was a great admirer of Islamic mystic thinker Ibn Arabi and a defender of the esoteric way (tariqa) of access to divine truth; his books written in French on the great saints were discussed by Louis Massignon. More importantly, the academic book he published in 1924 devoted to history of mystics gathered Greek, Jewish, Neoplatonician, Christian and Islamic mysticism; the book was indebted to the French tradition of the history of religions of the 19th century and refered to Adolphe Franck and Edouard Schuré. History of tasavvuf was taught at the very end of Ottoman period at the superior level of the medrese, taking place in the Kalam-Tasavvuf-Philosophy department that was created in 1914, at a time where there were many oppositions 
to the academicization of tasavvuf among many Sufis. A.'s teaching went further in this broad epistemological frame: his syncretic understanding of esotericism combined Sufism, mysticism and spiritualism, whether they were Islamic, Asian or Western. He equated "esotericism" with batinism (Islamic currents refering to inner and secrecy). His conceptions were heir of some important developments in the Late Ottoman intellectual field, where institutionnal and epistemological boundaries between spiritualism, philosophy and psychology were not fixed: the analogies made between Western philosophies and mystical thinkers of Islam, the historicization of religion and classical Islamic knowledge, and the huge interest in spiritualism in particular in the 1910s, some Ottoman intellectuals having developed the idea that Western spiritism was part of Islamic tradition and cosmology, and therefore very well represented in Islamic esoteric traditions. With the question of transmigration of souls (tenasüh) A. associated bektashism, one of the main Sufi orders, and theosophy; this was also favored by his interest in Rudolf Steiner's anthroposophy and his meeting with Carl Vett for whom the initiatory rituals and the modifications of the states of consciousness in Sufi brotherhoods made them similar to Western occult societies. A. remains in the academic literature as one of the artisans of a Turkish esotericism having appropriated Western and Eastern referents and as one representative of the early republican institutional ambiguity between hegemonic religious teachings, esoteric ones, and secularized knowledges.

Aksüt, Ali Kemali. Profesör Mehmet Ali Ayni ve Eserleri. Istanbul: Ahmet Sait Matbaası 1944.; Ayni, Mehmet Ali. Tasavvuf Tarihi. Istanbul: Orhan matbaasi 1924.; —. Intikad ve mülahazalar: Tasavvuf Tarihi. Istanbul: Orhaniye 1923.; Zarcone, Thierry. "Occultism in an Islamic context: The case of Modern Turkey from the nineteenth century to the present time." In Occultism in a Global Perspective, edited by Henrik Bogdan and Gordan Djurjevic, 151-176. London and New York: Routledge, 2013. 


\section{Beckh, Hermann (1875-1937)}

\section{Helmut Zander}

Born into the Protestant entrepreneurial family of Eugen B. and his wife Marie, née Seiler. In 1911 he came into contact with Rudolf Steiner, in 1912 he joined the Anthroposophical Society and in the same year became a member of the Esoteric School. In 1922 he belonged to the founding circle of the Christian Community inspired by Rudolf Steiner. Until his death, he was a pastor of this church.

Beckh completed his law studies with an award-winning writing, but then studied Indian and Tibetan philology. In 1907, he received his doctorate and finally wrote his habilitation on Kalidasa's Meghaduta, which he critically edited, translated and commented on; the works were highly praised by many scientific critics. He taught at Berlin University as a private lecturer and edited the Tibetan manuscripts in the Royal Library. After the First World War he declined a teaching position for Tibetan philology and was to be appointed associate professor. In 1921 he renounced his private lectureship. His many publications since the 1920s are spiritual works deeply influenced by anthroposophical ideas.

The comparison between the first (1916), second (1922) and third editions (1928) of his survey of Buddhism (Buddha und seine Lehre) shows the increasing anthroposophical impregnation of his scientific work. In 1916 he took the position that Buddhism and Christianity were categorically different and that the aim of studying Buddhism was "only" "to gain a deepening of religious knowledge and religious life” (p. 16). In the completely revised passage of 1928 Buddhism in its relationship to Christianity is reinterpreted with Steiner's terms. "Golgatha" is now, in taking over an utterance of Steiner in his biography of 1925, a "fact" "which is not attainable to a research working only with external historical documents," thus only by supernatural knowledge (p. 15). It remained still a task of Buddhism to promote the "deepening of religious knowledge" (p. 16), but only classified into the anthroposophical theory of the evolution of cultures. In Christianity "a stage of development beyond the preChristian Buddhist can be found" which makes possible the development of the "I-personality" (p. 15). Moreover, the criticism of theosophy is withdrawn from the first edition, but not eliminated.

Kacer-Bock, Gunhild. Hermann Beckh; online:

http://biographien.kulturimpuls.org/detail.php?\&id=48 (16.2.19).; ——. Hermann Beckh: Leben und Werk. Stuttgart: Urachhaus 1997; Beckh, Hermann. Verzeichnis der tibetischen Handschriften der Königlichen Bibliothek zu Berlin.

Ә Open Access. (c) 2021 Yves Mühlematter and Helmut Zander, published by De Gruyter. (c) BY-NC-ND This work is licensed under the Creative Commons Attribution-NonCommercial-NoDerivatives 4.0 International License. 
Berlin: Behrend \& Cie / Berlin/Heidelberg: Springer, 1914; —_. Beiträge zur tibetischen Grammatik, Lexikographie, Stilistik und Metrik. Berlin: Verlag der Königlichen Akademie der Wissenschaften 1908; —_. Buddhismus (Buddha und seine Lehre). Berlin/Leipzig: Göschen ${ }^{1} 1916 ;-$ _ Buddhismus (Buddha und seine Lehre). Berlin/Leipzig: de Gruyter ${ }^{2} 1922 ;-$ _ Buddhismus (Buddha und seine Lehre). Berlin/Leipzig: de Gruyter ${ }^{3} 1928 ;-$. Die tibetische Übersetzung von Kālidāsas Meghadūta. Berlin: Verlag der Königlichen Akademie der Wissenschaften 1906. 


\section{Coomaraswamy, Ananda Kentish (1877-1947)}

\section{Mark Sedgwick}

Born in Colombo, Ceylon (now Sri Lanka) to a distinguished Tamil father, Sir Mutu Coomaraswamy, and an English mother. C. grew up mostly in England, returning to Ceylon in 1903 as director of the mineralogical survey of Ceylon. His interests were already wide, however, and his early work reveals him as a Neoplatonist; he was also in contact with Swami Vivekananda through a friend, Sister Nivedita (born Margaret Elizabeth Noble). While in Ceylon C. became interested in South Asian art, to which he devoted the rest of his life. He built up a notable private collection, and moved to the US in 1917, becoming first keeper of Indian art and then research fellow at the Boston Museum of Fine Arts, where he remained until his death in 1947. During this period he contacted the French esotericist René Guénon, becoming a close collaborator from 1935 until his death.

C. was famous mostly for his work on South Asian art, notably his History of Indian and Indonesian Art (1927). This and similar works were foundational for an entire field of study, and are not overtly esoteric works, but reflect C.'s conviction that in order to understand it, a work of art should be placed in its cultural, religious and metaphysical context.

C. is known to followers of Guénon for his many articles in Études Traditionnelles, Guénon's journal, which contributed to Guénon's project of recovering the perennial tradition. C. shared Guénon's overall vision and contributed his knowledge and scholarship, and was especially important for the incorporation of Buddhism into the Guénonian scheme.

C. also wrote for a broader general audience, notably in The American Review. C. applied Guénonian perennialism to both South Asian religion (especially in Hinduism and Buddhism, 1943), and to art, in books and articles, and. He argued in "What Is the Use of Art Anyway?" and "Is Art a Superstition or a Way of Life?" (1937) for the understanding of art as "the making well, or properly arranging, of anything whatever that needs to be made or arranged" and lamented that working men had been reduced to brutes because production for profit had replaced production for use (i.e. art). This view fitted with both the views of the Arts and Crafts movement of William Morris, with which C. had been loosely associated, and with the Guénonian vision of traditional society as built around caste, a vision for which C. argued in Spiritual Authority and Temporal Power in the Indian Theory of Government (1942). Mircea Eliade wrote appreciatively of C.'s work.

Ә Open Access. (c) 2021 Yves Mühlematter and Helmut Zander, published by De Gruyter. (c))BY-NC-ND This work is licensed under the Creative Commons Attribution-NonCommercial-NoDerivatives 4.0 International License. 
Coomaraswamy, Ananda Kentish. Christian and Oriental Philosophy of Art. New York: Dover, 1956. Lipsey, Roger. Coomaraswamy: Selected Papers, Traditional Art and Symbolism. Vol. 1. Princeton: Princeton University Press, 1977; — . Coomaraswamy: Selected Papers, Metaphysics. Vol. 2. Princeton: Princeton University Press, 1977; — Coomaraswamy: His Life and Work. Vol. 3. Princeton: Princeton University Press, 1977. 


\section{Ehrenfels, Baron Omar (Umar) Rolf von (1901-1980)}

\section{Reinhard Schulze}

1901 born in Prague to Baron Christian von Ehrenfels (1859-1932) professor of philosophy at Prague University, and his wife Emma (1862-1946, née André). 1922-1923 he had to attend the forestry schools in Tharandt near Dresden and in Eberswalde near Berlin to prepare for the planned takeover of the family estate. At the same time, he worked as recording director of an American-German film company and thus travelled the Balkan states and Turkish territories, which arose his ethnological interest. He also met his first wife Ellen Feld there and married her shortly afterwards. This marriage did not last long; already in 1925 he married Elfriede (von) Bodmershof (1894-1982); E. still tried to make a career as author and journalist in Berlin. In 1927, he converted to Sufi Islam in the Ahmadi context in Berlin and called himself Omar (later Umar). In Berlin, the couple intensively studied Christian E.'s major work Kosmogonie (Jena 1916). This work, which E. wanted to follow with a book entitled Theogonie as the basis of a new religion, claimed to be a world explication "from within." In 1932 he travelled to India for a year to process his father's death; after his return he studied ethnography at the University of Vienna. In Vienna he also presided over the Orientbund till 1938. After completing his anti-aryanist dissertation on Mother-right in India (1937), he had to flee first to Greece, then to India in 1938/ 9. Elfriede did not follow him. The marriage was divorced at the end of the 1940s. In India, he had to live in an internment camp from 1940 to 1946 . He married the French social scientist Mireille Abeille (1924-2007) in 1948. From 1949 to 1961 E. was head and professor of the Department of Anthropology at Madras University. In 1961 he settled to Germany and helped to establish the South Asia Institute at the University of Heidelberg. E. died in Neckargemünd (Heidelberg, Germany) in 1980.

E. initially published numerous smaller works in the Prager Tageblatt, published by Max Brod (1884-1968). He translated his dissertation Mutterrecht in Vorderindien, (typescript, Vienna 1937) and published it as Mother-right in India in Hyderabad in 1941; he further developed and elaborated his anti-aryanist reconstruction of a primordial Matriarchal System in India (cf. "Traces of Matriarchal civilization among the Kolli Malaiyalīs”, Journal of the Asiatic Society of Bengal 3:9 Letters, 1943, 29-82). In Madras, he wrote his monograph on Kadar of Cochin which he called a Tribal monograph. Later in 1960, he published his book The Light Continent, in which he described his experience as an ethnographer in East Africa in the 1950s. As his father, E. seldom hid his esoteric understanding of scientific worldviews. He clearly defined a primacy of a primordial matriarchical

Ә Open Access. (c) 2021 Yves Mühlematter and Helmut Zander, published by De Gruyter. (c))BY-NC-ND This work is licensed under the Creative Commons Attribution-NonCommercial-NoDerivatives 4.0 International License. https://doi.org/10.1515/9783110664270-013 
order which left its traces in particular in Indian societies. For him, the East represented the female principle still represented in Yantra, mandala and yoga traditions ("Mandala und das weibliche Prinzip", in: Esotera 26 (1975), 212-219). In this, he followed his father's interpretation of "Motherright" which reflected the neo-matriarchical views as promoted by Johann Jakob Bachofens (1815-1887) and others (Christian von Ehrenfels, "Die Ehe nach Mutterrecht", in: PolitischAnthropologische Revue 11 (1906) 4, 633-647).

Ehrenfels, Christian von. System der Werttheorie. Vol. 1. Allgemeine Werttheorie: Psychologie des Begehrens. Leipzig: Reisland, 1897; Jonker, Gerdien. "In Search of Religious Modernity: Conversion to Islam in Interwar Berlin." In Muslims in Interwar Europe: A Transcultural Historical Perspective, edited by Bekim Agai, Umar Ryad, and Mehdi Sajid, 18-46. Leiden: Brill, 2016; Polzin, Julia. "Matriarchale Utopien, freie Liebe und Eugenik: Der Bund für Mutterschutz im Wandel zeitgenössischer Ideen und politischer Systeme.” PhD diss., Univ. Hamburg, 2016; Ryad, Umar, "Salafiyya, Ahmadiyya, and European Converts to Islam in the Interwar Period." In Muslims in Interwar Europe: A Transcultural Historical Perspective, edited by Bekim Agai, Umar Ryad, and Mehdi Sajid, 4787, Leiden: Brill, 2016. 


\section{Faivre, Antoine (*1934)}

\section{Helmut Zander}

Antoine Faivre was born in Reims in 1934. Raised as a Catholic, he became a convinced Christian during his military service in Algeria in 1961. F. studied amongst others German literature and history of religions at the Sorbonne. He earned his doctorate with two works on the German romantic natural philosophers Niklaus Anton Kirchberger and Karl von Eckartshausen (1966/1969). In 1969 he became Freemason in the Grand Loge Nationale Française and practiced the Martinist Rite Ecossais Rectifié; he had been referred to Freemasonry by the Jesuit Michel Riquet, a member of the French resistance who was very well known in France at that time. Two members of the Eranos Circle, Henry Corbin and Gilbert Durand, both of whom he introduced to his Masonic tradition, became formative academic teachers for him. F. himself had participated in meetings of the Eranos Circle since 1967, but as "homme de gauche" he had developed a distance to the political positions in this circle. Especially under the influence of Corbin, whom F. called his "maître", he developed the conviction of an independent spiritual reality. In 1974 he co-founded the Université Saint Jean de Jérusalem, where scholars sought to combine their religionist positions with excellent scientific research. Nevertheless, F. considered himself a Catholic Christian. In 1979 Faivre was called upon to the Chaire d'Histoire des courants ésotériques et mystiques dans l'Europe moderne et contemporaine at the École Pratique des Hautes Études in Paris, where he prevailed against Michel de Certeau.

In the course of his academic life, F. increasingly distanced himself from perennialist positions. F. himself sees an important stimulus in the 1968/1969 student movement in Paris, but his stays at the University of Berkeley and his encounter with contemporary esotericism on the American West Coast in the 1980s probably played a decisive role. F. became a scholar who applied historical and critical methods and distinguished strictly between normative and analytical approaches to his field of research. Wouter Hanegraaff sees this reorientation of F.'s understanding of science, which approached a break with his older positions, accomplished in the book L'ésotérisme of 1992. With the conception of esotericism developed there, F. became the founder of scholarly research on esotericism.

Faivre, Antoine. L'ésotérisme (Que sais-je 1031). $6^{\text {th }}$ ed. Paris: Presses Universitaires de France 2019. First published 1992 by Presses Universitaires de France (Paris); Hanegraaff, Wouter Jacobus. Esotericism and the Academy: Rejected Knowledge in Western Culture, 339-355. Cambridge: Cambridge University

Ә Open Access. (c) 2021 Yves Mühlematter and Helmut Zander, published by De Gruyter. (c) BY-NC-ND This work is licensed under the Creative Commons Attribution-NonCommercial-NoDerivatives 4.0 International License. https://doi.org/10.1515/9783110664270-014 
Press 2012. Additional information derives from an interview with F. on June $8^{\text {th }}$, 2019, and from documents from the estate of Henry Corbin at the École Pratique des Hautes Études, Collections patrimoniales, Fonds chiite, whose insight was enabled by a scholarship from the EU-project "Research Infrastructure on Religious Studies"; I especially thank Alfonsina Bellio and Morgan Guiraud for their help. 


\section{Johnston, Charles (1867-1931)}

\section{Yves Mühlematter}

J. was born in 1867 and grew up in a loyalist Protestant environment. His father was an Orangeman, and later became the order's Deputy Grand Master of Ireland and a Member of Parliament for Belfast. J. was educated at Derby, then studied at the University of Dublin, where he learned Sanskrit and Russian. He was probably awarded a BA and an MA from the University of Dublin. In 1884, when he was 17, he read Sinnett's The Occult World. Shortly after, he joined the Theosophical Society. His first article appeared in 1886 in The Theosophist, when he was only 19 years old. Throughout his life J. translated numerous Indian texts, among them the Bhagavadgitā and several Upaniṣads. In 1912 he translated Paul Deussen's Das System des Vedânta ${ }^{1}$ into English.

At an occasion at Blavatsky's house, J. met Vera (née de Zhelihovsky, 1864-1923), the niece of Madame Blavatsky. He married her in 1888, shortly before he departed to India to participate in the Civil Service. The Johnstons only stayed in India for two years, because J. came down with malaria. After the schism within the Theosophical Society, J. remained loyal to Quan Judge. After Judge's death, the Johnstons finally relocated to New York City. J. and his wife became leading members of the Hargrove branch of the Theosophical Society. He lectured on many occasions for the Theosophical Society and therefore travelled on a regular basis between America and Europe.

In addition, he taught private Sanskrit classes, was a "Special Lecturer in Political Science at the University of Wisconsin", delivered "a number of addresses at Columbia University in New York," "was a valued member of the Linnaean Society" and "served as Captain in the Military Intelligence Division at Washington". 2 The influence of J. on Religious Studies is difficult to trace. However, his translations of numerous Indian texts into English are believed to have had a major influence on the American reception of Indian religion, both inside and outside academia.

The Johnstons were active members of the Russian Orthodox Church in New York. They gave courses at the seminary of the Church. In addition, Vera Johnston was responsible for the shop of the church at the Russian bazar in New York (New York Times, 3/28/1915). J. died in 1931 at St. Luke's Hospital in New York City from heart disease.

1 "The System of the Vedanta"

2 H.B.M. [Mitchell Henry Bedinger] 1932, S. 211.

Ә Open Access. (c) 2021 Yves Mühlematter and Helmut Zander, published by De Gruyter. (c))BY-NC-ND This work is licensed under the Creative Commons Attribution-NonCommercial-NoDerivatives 4.0 International License. https://doi.org/10.1515/9783110664270-015 
Bedinger Mitchell, Henry. “Charles Johnston.” The Theosophical Quarterly (1932): XXIX; Fergus, Jon W. Charles Johnston: A Biography. Accessed March 5, 2019, http://www.universaltheosophy.com/bios/charles-johnston; Namee, Matthew: Orthodoxy and Theosophy: The Vera Johnston Story. Accessed March 5, 2019, http:// orthodoxhistory.org/2010/08/05/orthodoxy-and-theosophy-the-vera-johnston-story; Mühlematter, Yves. “Charles Johnston's Interpretation of "Yoga”: Theosophy, Consciousness, and Spiritual Progress.” In Contemporary Yoga and Sacred Texts, edited by Susanne Scholz and Caroline Vander Stichele. London: Routledge, forthcoming. 


\section{Kamensky, Anna (1867-1952) (Anna Alexeyevna Kamenskaya)}

\section{Florence Pasche Guignard}

1867 born in Pavlosk, in Russian nobility. 1869, after her father's death, women of her family left Russia and established themselves first in Germany, then in Geneva. 1875-1882 K. studied in Geneva, then returned to Saint Petersburg. Due to the dire financial situation of her family, she worked as a teacher. She engaged in activism for social justice and women's issues. 1896-1900 K. took up her studies again. 1887 onwards, K. started turning away from Orthodox Christianity. Around 1890, her friend Nina Gernet introduced K. to the Theosophical Society (TS). K. became an independent member of the English section. $1902 \mathrm{~K}$. attended lectures by Annie Besant in London. $1904 \mathrm{~K}$. started a theosophical circle in Petersburg. 1908 she founded an official Russian section of the TS and acted as its first general secretary. K. maintained and expanded her national and international networks, attended conferences, gave lectures, and published numerous articles. She launched the Vestnik Teosofii (Theosophy Messenger) magazine. 1916 K. and her sister Margarita lived for over one year in Adyar (India) at the general headquarters of the TS. She translated the Bhagavadgitā from Sanskrit into Russian. After the October Revolution, the situation deteriorated for members of the TS and in 1918 their activities were forbidden. $1921 \mathrm{~K}$. fled with her friend and associate Cecilia Helmboldt to escape arrest. Settled in Geneva, K. and Helmboldt became involved in the Swiss section of the TS, with K. presiding the lodge "Paix et Lumière." 1924 K. organized the "Russian Theosophical Society out of Russia."

Under her leadership and influence, many of K.'s theosophical activities took place in collaboration with other women who formed around her professional, social, and spiritual networks. Such moral and material support was more significant than that of academic institutions. K. died in Geneva in 1952.

K. published mostly in non-academic venues. Her most significant scholarly contributions are her translations and her academic teaching. In 1926, after a two-year process involving administrative struggles, the University of Geneva granted K. her doctoral degree for her translation into French of the Bhagavadgit $\bar{a}$ with considerations on "its role in the religious movement of India and its unity." Her own spiritual inspirations were noticeable in this dissertation. 1927-1951 K. taught courses in religious studies at the Faculté des Lettres as a "privat-docent" but never had the title of professor. The detailed list of titles of her courses, found in the University's archives, gives some indications on her epistemology, methodology, and on her phenomenological perspective: "Introduction to the comparative study of religions: history of religions, philosophy of Religion, science of religions, comparative study of religions,

Ә Open Access. (c) 2021 Yves Mühlematter and Helmut Zander, published by De Gruyter. (c))BY-NC-ND This work is licensed under the Creative Commons Attribution-NonCommercial-NoDerivatives 4.0 International License. https://doi.org/10.1515/9783110664270-016 
fraternity of religions, religious experience.” K. taught other courses on Vedic and classical India, the Bhagavadgitā, the Mahābhārata, spiritualities in modern India, philosophy, and aesthetics. The notion of "fraternity" or "brotherhood" of religions points out to how her theosophical ideas influenced the way she taught about religions in academic settings.

Carlson, Maria. 'No Religion Higher Than Truth:' A History of The Theosophical Movement in Russia, 1875-1922. Princeton: Princeton University Press, 1993; Fedorovna Pisareva, Elena, and Algeo, John, ed., The Light of the Russian Soul. A Personal Memoir of Early Russian Theosophy. Translated by George M. Young. Wheaton: Quest Books, 2008; Mayer, Jean-François. Les nouvelles voies spirituelles: Enquête sur la religiosité parallèle en Suisse. Lausanne: L’Age d'Homme, 1993. 


\section{Mead, George Robert Stow (1863-1933)}

\section{Helmut Zander}

M. was born in 1863 to British Army Colonel Robert Mead and his wife Mary (née Stow). In 1883 he read Sinnett's Esoteric Buddhism. One year later he received the BA degree in Classics (Greek, Latin) and became a member of the Theosophical Society. In 1889, he was appointed Blavatsky's private secretary and joint-secretary of Esoteric Section. In the same year he married to the Theosophist Laura Mary Cooper. 1909 M. left the Theosophical Society because of the reinstatement of Leadbeater. As a response, he founded the Quest Society to continue esoteric and scholarly research. M. died in London 1933.

M. was a translator of many gnostic writings into English, including those that had not previously been translated (such as: Pistis Sophia 1896, ${ }^{2} 1921$; Thrice Greatest Hermes, 3 vol., 1906; The Complete Echoes from the Gnosis, 1906-1918). As a trained classical philologist, he had important prerequisites. M. became particularly famous through the translation of the Pistis Sophia. There are no studies on the academic reception of his works. However, his translations were widely used, in part due to the fact that they were often without alternatives. Already at the end of the $19^{\text {th }}$ century, but finally in the $20^{\text {th }}$, his works were increasingly less state-of-the-art.

There is no analysis of his translations with regard to their theosophical implications. The theosophical relations are in particular visible in the comments. In addition to correct scientific analysis, such as codicological descriptions, theosophical ideas are included here. For example, gnostic writings are for M. documents of mystery communities with secret knowledge and initiated disciples. Thus he writes (but only in the second edition of the Pistis Sophia): "It is evident, however, that the P.S. was never intended to be circulated as a public gospel. ... Certain mysteries ... the recipients were to bestow under certain conditions, but others were to be reserved. . . . The P.S. was intended for already initiated disciples, for chosen learners, though no pledge of secrecy is mentioned." (p. xlviii f.) The concept of interpreting Jesus in the context of a story of reincarnation (p. xlv f.) also originated from theosophical ideas.

In the Quest Society, he attracted a lot of well-known intellectuals, as Martin Buber, Robert Eisler, Gustav Meyrink, and William Butler Yeats. 1931 he was invited to the Eranos Circle, but did not attend. M. was a member of the Royal Asiatic Society, where he gave his last public lecture before his death.

Godwin, Joscelyn. "Mead, George Robert Stowe.” In Dictionary of Gnosis and Western Esotericism, edited by Wouter J. Hanegraaff, Antoine Faivre, Roelof van den Broek and Jean-Pierre Brach. Vol. 2, 785-786. Leiden/Boston: Brill, 2005;

Ә Open Access. (c) 2021 Yves Mühlematter and Helmut Zander, published by De Gruyter. (c))BY-NC-ND This work is licensed under the Creative Commons Attribution-NonCommercial-NoDerivatives 4.0 International License. https://doi.org/10.1515/9783110664270-017 
Mead, George Robert Stow. Pistis Sophia: A Gnostic Gospel. $2^{\text {nd }}$ rev. ed. London: Theosophical Publishing Society, 1896; —_. Pistis Sophia: A Gnostic miscellany. London: Watkins, 1921. 


\section{Méautis, Georges (1890-1970)}

\section{Léo Bernard}

Georges Méautis was born in 1890 in Montreux (Switzerland) and pursued an education in Classical Studies (Lausanne, Neuchâtel, Munich, Paris). He was registered as a member of the Theosophical Society on the 7th of February 1918 and as a member of the Order of the Eastern Star on the 9th of April. He defended his thesis in papyrology in July of the same year under the title Une métropole égyptienne sous l'empire romain. Hermoupolis-la-Grande, a city considered to be the cradle of Hermeticism, and quickly found a position at the University of Neuchâtel: as privat-docent in 1919, then professor of Greek language and literature and classical archaeology (1920-61), dean (1930-35), and rector (39-41). He also held responsibilities in the Swiss Section of the Theosophical Society: branch president, archivist and general secretary (1926-29), and was admitted into the E.S. around 1922, before being baptised in the Liberal Catholic Church in September 1923. He distanced himself from the T.S. during the early 1930s, but still maintained, although intermittently, a certain level of contact. He left behind him a substantial bibliography in 1970 .

M. was first and foremost a respected professor of Classical Studies who specialised in Greek religion and received many academic distinctions: doctor honoris causa from Athens University (1937), Schiller award (1950), and corresponding member of the Institut de France (1952). His prominent position at Neuchâtel University led several professors to pay him tribute through a book published for the centenary of his birth in 1990. His academic credentials notwithstanding, M. was during the early stages of his career a devoted theosophist. Under the pen name of Archytas, he published in a theosophical periodical a collection of four articles entitled "Ancient Theosophy" whose goal was to assemble "some fragments from the theosophists of ancient Greece which may be difficult for the layman to access and which confirm the teachings of our instructors." In a similar vein, his interest in the question of the verifiability of clairvoyance led him to the investigation of the eventual proximity between an obscure treatise by Plutarch and the writings of Leadbeater and Besant on the topic of the aura. He later cautiously expanded this historical comparison in his own translation of the treatise published in 1935, and perhaps surprisingly, the book was well-received even in academic journals. Moreover, in his translation of The Golden Verses of Pythagoras, M. acknowledged his scholarly indebtedness to "the secret tradition passed down by a certain esoteric school, a tradition which inspired these two treasures of initiatory literature: Light on the Path and The Voice of the Silence." He employed these two often mentioned theosophical

Ә Open Access. (c) 2021 Yves Mühlematter and Helmut Zander, published by De Gruyter. (c))BY-NC-ND This work is licensed under the Creative Commons Attribution-NonCommercial-NoDerivatives 4.0 International License. https://doi.org/10.1515/9783110664270-018 
books to help him in the translation of the original text and to justify some corrections made to earlier scholarly translations. While underlining this influence, the American scholar Edith Owen Wallace (1892-1976), who positively reviewed M.'s work in The Classical Weekly, made the following assessment: "However daring that argument may be in construction of a text, it comports with M. Méautis' comparative method.” Indeed, parallels of this nature were a common feature of M.'s celebrated works on Greek philosophy and mystery cults.

Fonds Georges Méautis, GMEA ms 2121. Bibliothèque publique et universitaire de Neuchâtel, Neuchâtel, Switzerland; Archytas [Méautis, Georges]. "Une vérification historique [des enseignements théosophiques]." Le Lotus Bleu (January 1921): 432-439; —_. "La Théosophie antique." Le Message Théosophique et Social (7 December 1919): 135; Bertrand, Paul [Méautis, Georges]. Theosophy and Theosophism: Response to a Criticism of Theosophy by René Guénon. Translated by Joscelyn Godwin. FOTA Special Edition, Autumn 2016; Knoepler, Denis, ed. Mnêma pour Georges Méautis. Neuchâtel: Séminaire des sciences de l'antiquité classique de l'Université de Neuchâtel, 1991; Méautis, Georges, trans. Plutarque: Des délais de la justice divine. Lausanne: Les amitiés Gréco-Suisses, 1935; ——. trans. Le Livre de la Sagesse pythagoricienne. Paris: Durbon Ainé, 1938; Schneider, André. "Georges Méautis (1890-1970)." In Histoire de l'Université de Neuchâtel. Tome 3, 353-356. Hauterive: Université de Neuchâtel et Editions Gilles Attinger, 2002; The International Theosophical Year Book 1937. Adyar: The Theosophical Publishing House, 1937; Wallace, Edith Owen. Review of Le Livre de la Sagesse pythagoricienne, by Georges Méautis. The Classical Weekly 34, no. 18 (24 March 1941): 211-212. 


\section{Rousselle, Erwin (1890-1949)}

\section{Karl Baier}

R. had a Huguenot family background. In 1911 he became a freemason. Eight years later he was accepted into the Swedish Rite, a Christian high degree system, by the Coronata lodge in Mannheim. He reached the highest degree of this rite in 1921. R. also functioned as orator of the Johannis lodge Zum flammenden Schwert in Darmstadt. Within this lodge he got into close contact with Carl Happich and Karl Bernhard Ritter who belonged to a German protestant reform movement called Berneuchener Bewegung. During his stay in Darmstadt R. also held a leading position as teacher and a kind of master of the ceremonies in Hermann Keyserling's School of Wisdom. Within this context he developed a system of spiritual practices that was inspired by the Ignatian exercises and focussed on Parsifal and the mystery of the Holy Grail. The School of Wisdom regularily offered retreats on this basis between 1921 and 1924. R.'s book on the mystery of transformation (Mysterium der Wandlung, 1923), a comparative study of the stages of spiritual development within different religions, was meant to be a theoretical foundation of his exercises. Additionally, R. participated in the conferences of the School of Wisdom and contributed to Keyserling's journals Der Leuchter and Der Weg zur Vollendung. During his first stay in China he was initiated into a Daoist secret society. In the 1930ties Rousselle became an important lecturer within the Eranos conferences. At the end of his life he converted to the Catholic Church.

After doctorates in Semitic studies and law as well as extended studies of an impressive number of languages, R. got a habilitation degree in oriental and occidental comparative philosophy (Vergleichende Philosophie des Morgen- und Abendlandes) from the University of Darmstadt in 1923. He thus became the first German university lecturer with a qualification in comparative philosophy. From 1924 to 1930 he worked as lecturer and professor for German philosophy at the Imperial University of Beijing and the Tsing Hua College, Beijing. Before his return to Germany in 1929 he twice spent several months in Japan to deepen his Japanese studies. In 1930 he became the successor of Richard Wilhelm as head of the China Institute, University of Frankfurt, in 1935 associate professor for sinology and Buddhist studies also at the University of Frankfurt. Between 1938 and 1940 he again stayed in China to investigate the Chinese religions. Back in Germany, he had to suffer from severe repressions through the Nazi regime. He lost the allowance to teach and his post at the China Institute. Additionally he was forbidden to speak in public. 
R.'s life-long academic interest in meditation practices, spiritual direction and personal transformation can only be understood against the background of his involvement within esoteric societies and the School of Wisdom.

Fenske, Wolfgang. "Rousselle, Erwin.” In Biographisch-bibliographisches Kirchenlexikon (BBKL), vol. 31. Sp. 1160-1163. Nordhausen: Bautz, 2010; Hakl, Thomas. Eranos: An Intellectual History of the Twentieth Century. Sheffield and Bristol: Equinox Publishing Ltd, 2013; Rousselle, Erwin. Mysterium der Wandlung: Der Weg zur Vollendung in den Weltreligionen. Darmstadt: Otto Reichl, 1923; — . " "Grundriss der Ordenswissenschaft." In Zirkelkorrespondenz der Großen Landesloge der Freimaurer von Deutschland 1926, 5, 111-120 and 8, 169-179 (n.d.); — Z Zur seelischen Führung im Taoismus: Ausgewählte Schriften. Darmstadt: Wissenschaftliche Buchgesellschaft, 1962; Walravens, Hartmut. "Erwin Rousselle (Hanau 8. April 1890 - Eschenlohe/Obb. 11. Juni 1949). Notizen zu Leben und Werk.” Monumenta Serica 41 (1993): 283-298. 


\section{Schrader, Friedrich Otto (1876-1961)}

\section{Judith Bodendörfer}

S. was born on March $19^{\text {th }}, 1867$ in Hamburg. He studied Philosophy, Indology and comparative linguistics in Göttingen, Kiel and Strasbourg, where he received a doctorate summa cum laude with a dissertation on Indian philosophy in 1902. After that, S. spent some time in Leipzig and Berlin. During this time, if not before, he came in contact with members of the Theosophical Society. In 1905 he went to London, where he was subsequently appointed librarian of the theosophical library in Adyar by H. S. Olcott. Before his departure to India in the same year, he married Lucie Bennoit from Neuchâtel (CH), who followed him to India in 1907. With the beginning of World War I in 1914, S. was interned by the British while his wife and children returned to Switzerland. S.'s friend and deputy, the Dutch Tibetologist Johan van Manen, took over the direction of the theosophical library during this period. In 1916, S. officially resigned from his position. After his release in 1920, S. joined his family in Switzerland. In 1921, he was appointed professor for Indology at the University of Kiel. S. retired as a professor in November of 1945 but was the head of the Indo-Germanic seminary in Kiel from 1947 until 1950. He died on November $3^{\text {rd }}$, 1961 in Kiel.

S. was a well-connected Indologist who strengthened the links between the Adyar library and "western" academic researchers. All his life he stayed committed to the Theosophical Society. In 1904, before his time as a librarian at Adyar, S. wrote the article Maya-Lehre and Kantianismus (Maya Teachings and Kantian Philosophy), which was published in the magazine Theosophisches Leben and as offprint by the theosophical publisher Paul Raatz in Berlin. The article pleads for the acceptance of the epistemological concept of "feeling". S. argued that, from the standpoint of the Maya teachings, reason (unlike "feeling") was not able to discern truth, as it confused sensory perception with reality. Very similar arguments against "Western" science and especially against the "father of the science of religion”, F. M. Müller, had been produced by theosophists before, notably by the pandit G. Krishna Sastri, who was to be S.'s colleague at the Adyar library. Although Maya-Lehre and Kantianismus was heavily criticized by S.'s former teacher, the famous Indologist Paul Deussen, related claims became common in the phenomenological branch of the study of religion during the first half of the $20^{\text {th }}$ century.

Bodendörfer, Judith. “Friedrich Max Müllers 'Science of Religion' in Auseinandersetzung mit der Theosophischen Gesellschaft” (PhD. diss. University of Fribourg, working title, forthcomming); Deussen, Paul. "Maya-Lehre und Kantinismus.” Indogermanische Forschungen 17,1 (1905): 7-8; Krishna Sastri,

Ә Open Access. (c) 2021 Yves Mühlematter and Helmut Zander, published by De Gruyter. (c))BY-NC-ND This work is licensed under the Creative Commons Attribution-NonCommercial-NoDerivatives 4.0 International License. https://doi.org/10.1515/9783110664270-020 
Ganapati: "Prof. Max Müller on the Secret Doctrine.” Theosophist 23 (1902): 727-733; Schrader, Friedrich Otto. "Maya-Lehre und Kantianismus." Theosophisches Leben VII (1904/1905): 17-19, 76-81, 131-135; Sprockhoff, Joachim Friedrich. "Friedrich Otto Schrader zum Gedächtnis.” Zeitschrift der Deutschen Morgenländischen Gesellschaft 113,1 (1963): 1-11. 


\section{Seidenstücker, Karl Bernhard (1876-1936)}

In memoriam Heinz Mürmel (1944-2019)

\section{Yves Mühlematter}

S. was born in 1876 near Halle and Leipzig. His father was "Superintendent" and "Oberpfarrer" of the Protestant church and educated S. until 1894, when he joined the "Königliche Domgymnasium." He studied, among other subjects, philosophy and "indische Philologie," under such well known professors as Franz Kielhorn, August Conrady, Richard Pischel, Ernst Windisch and Theodor Zacheriae. ${ }^{3}$

S. called himself a Buddhist from 1902 onwards. In 1903 he was a cofounder of the "Buddhistischer Missionsverein für Deutschland." In these years he published Die Greuel der christlichen Zivilisation and Buddha und Christus: Eine buddhistische Apologetik under a pseudonym. In 1903 and 1904, S. gave talks on Buddhism in a vegetarian restaurant in Leipzig which was frequented by Theosophists. S.'s wife was a Theosophist and he worked as an editor for Theosophical periodicals. In 1907, S. and his fellow Buddhists established the "Maha-Bodhi Centrale" (1911: "Deutsche Zweig der Mahabodhi-Gesellschaft"). Thanks to international contacts and the mediation of Paul Carus and C.T. Strauss, it was officially recognized by Anagarika Dharmapala. The boundary work against the Theosophical Society became one of S.'s major issues. In 1913 he left the "Mahabodhi-Gesellschaft".

S. returned to academic work and finished his dissertation on the Udāna under the supervision of Ernst Windish. S.'s translation of the Udāna is still a standard translation in German. In the following years, he worked for Georg Thilenius at the "Völkermuseum Hamburg." He became a member of the "Leipziger Institut für Kultur und Universalgeschichte" and planned to write a Habilitation, most likely under the supervision of Walter Goetz (Leipzig). During World War I, S. served in the battle of Verdun. His war experience, in addition to an illness, might explain why he never finished his Habilitation.

After the war, S. and Georg Grimm launched the Buddhist journal "Buddhistischer Weltspiegel." For S., who was interested in Buddhist contemplation techniques, Grimm's teaching led him to place more emphasis on inner spirituality. In 1928, S. moved to Munich, had himself and his daughters baptized in

3 Ulrich Steinke, "Karl Bernhard Seidenstücker (1876-1936) Leben, Schaffen, Wirken.” accessed May 13, 2019, http://www.payer.de/steinke/steink00.htm.

Ә Open Access. (c) 2021 Yves Mühlematter and Helmut Zander, published by De Gruyter. (c))BY-NC-ND This work is licensed under the Creative Commons Attribution-NonCommercial-NoDerivatives 4.0 International License. https://doi.org/10.1515/9783110664270-021 
the Catholic church, and attended mass regularly. In 1934, he suffered a stroke from which he never fully recovered and died in 1936.

Mürmel, Heinz. "Vortragsmanuskript: Der Beginn des institutionellen Buddhismus in Deutschland: Der Buddhistische Missionsverein in Deutschland (Sitz Leipzig)." In Erneuerungsbewegungen im Buddhismus. Buddhismus in Geschichte und Gegenwart 11. Universität Hamburg, Asien-Afrika-Institut, Abteilung für Kultur und Geschichte Indiens und Tibets. (Weiterbildendes Studium), 2006. https://www.buddhismuskunde.uni-hamburg.de/pdf/4publikationen/buddhismus-in-geschichte-und-gegenwart/bd11-k10muermel. pdf. Accessed March 18, 2019.; __ . "Buddhismus und Theosophie in Leipzig vor dem Ersten Weltkrieg." In Buddhisten und Hindus im deutschsprachigen Raum: Akten des zweiten Grazer Religionswissenschaftlichen Symposiums (2.-3. März 2000), edited by Manfred Hutter, 123-36. Religionswissenschaft Bd. 11. Frankfurt am Main, New York: Lang, 2001; Steinke, Ulrich. Karl Bernhard Seidenstücker (1876-1936): Leben, Schaffen, Wirken, 2007. Accessed July 29, 2016. http://www.payer.de/steinke/steink00.htm.; Usarski, Frank. "Merkmale der frühen deutschen Buddhismusrezeption: Ein revidierter systematischer Aufriss.” In Mauss, Buddhismus, Devianz: Festschrift für Heinz Mürmel zum 65. Geburtstag, edited by Thomas Hase, 233-52. Marburg: Diagonal-Verlag, 2009; Zotz, Volker H. M. Auf den glückseligen Inseln: Buddhismus in der deutschen Kultur. Berlin: Theseus, 2000. 


\section{Suzuki, Daisetsu Teitarō (1870-1966)}

\section{Hans Martin Krämer}

Born to a physician in Northern Japan in 1870, S. was an ardent practitioner of Zen, even while he was enrolled at Tokyo Imperial University to study languages in the 1890s. It was at this time that he was introduced to Zen meditation by Imakita Kōsen and Shaku Sōen at Kamakura's Engaku-ji temple, where he also met the Theosophist Beatrice Lane, whom he would later marry. In 1897 S. moved to the United States, where he worked at Paul Carus's publishing house Open Court. During his stay in the United States, S. came into contact with Swedenborgianism; in the 1910s, he became a member of the Japanese Swedenborg Society. In 1920, S. joined the Theosophical Society, becoming president of the International Lodge in Tokyo. Shortly thereafter, this lodge was disbanded and a new one, Mahayana Lodge, was founded in Kyoto in 1924, run by his wife. S. himself remained a member of that lodge until its demise in 1929. Since 1921, S. had been a professor at the Buddhist Ōtani University in Kyoto. He remained active scholarly until his death in 1966, with long spells of teaching in the United States.

S. is famous for having pursued the scholarly study of Buddhism and - most successfully - its propagation at the same time. He published scholarly works such as his translation of the Lankavatara Sutra from the original Sanskrit (1932), but the bulk of his numerous publications both in Japanese and in English are introductions to Zen Buddhism aimed at a larger audience. This popular strand of his may also have been responsible for his affirmative attitude towards Swedenborgianism and Theosophy, which he viewed as legitimate paths to spiritual fulfillment, by and large compatible with Buddhism.

At least this is true during the biographical phase of the "Occult Suzuki" (Tweed), beginning with his lecture before the Theosophical Society of San Francisco in 1903. Also, between 1910 and 1915, S. produced four book-length translations into Japanese commissioned by the Swedenborg Society, and in addition a monograph on Swedenborg in 1913. Next to the similarities to Buddhism he saw, S. was interested in Swedenborg because "there seems to be a spiritual realm separate from that of the five senses; and when we enter a certain psychological state, we apparently can communicate with that realm like we do with our own." To S., Swedenborg offered a new way to tackle the question of the afterlife, which had vexed modern Japanese Buddhists, by reaffirming its concreteness and a spiritual way of gaining access to it. 
In contrast, Theosophy received nary a mention in S.'s publications, and in his private correspondence, he is rather critical of it, despite his association with the movement (mainly through his wife) in the 1920s.

Algeo, Adele S. "Beatrice, Lane Suzuki and Theosophy in Japan.” Theosophical History 11/3 (2005): 3-16; Tweed, Thomas. "American Occultism and Japanese Buddhism: Albert J. Edmunds, D. T. Suzuki, and Translocative History.” Japanese Journal of Religious Studies 32, 2 (2005): 249-281; Yoshinaga, Shin'ichi. "Suzuki Daisetsu and Swedenborg: A Historical Background." In Modern Buddhism in Japan, edited by Hayashi Makoto et al., 112-143. Nagoya: Nanzan, 2015. 


\section{van Manen, Mari Albert Johan (1877-1943)}

\section{Karénina Kollmar-Paulenz}

1877 born to engineer R. O. van Manen and his wife Maria Albertina Johanna van Tricht at Nijmegen. From early youth interest in Asian philosophy and religions. Since 1895 active member of the Dutch Theosophical Society. 1897 translator for H.S. Olcott. 1898 meeting and collaboration with Annie Besant. In the same year he published a short life-account of her (Een korte levensschets). Representative of the Dutch branch at the Theosophical Society-Convention in London 1902. 1904 to 1906 Honorary Secretary of the first three Conventions of the TS. 1906 to 1916 private secretary to Leadbeater. 1908 to 1916 assistant director of the Library in the Theosophical Headquarters at Adyar, India. V. M. left Adyar because of grave differences with Annie Besant. In their book The Lives of Alcyone, Leadbeater and Besant constructed a reincarnation line for van Manen, which he rejected. In vain he tried to block the publication. In addition, Besant engaged politically during the First World War for the Allies, while van Manen was convinced that the Theosophy should remain neutral in worldly conflicts. After his move to Calcutta in 1918, employment by the Imperial Library, the Indian Museum and the Royal Asiatic Society of Bengal. He collected Tibetan texts and artefacts, his scholarly research focused on Tibetan Buddhism. V. M. probably remained a member of the Theosophical Society until his death in Calcutta 1943.

As a scholar, V. M. was mainly interested in the languages and religions of the Himalayan peoples. Although never formally educated at a university, he can be considered the first Dutch tibetologist. His scholarly interests covered Tibetan book production as well as oral literature. The van Manen collection of Tibetan books is nowadays kept at the Kern Institute at Leiden/Netherlands. He encouraged three of his Tibetan assistants to write down their life-stories, of which an edited English version was published in 1989. V. M. is nowadays mainly remembered for his Tibetan book collection and his bibliography of Tibetan literature (A Contribution to the Bibliography of Tibet, 1923).

No assessment of his scholarship with regard to theosophical influence exists. His first articles about Tibetan Buddhism are critical evaluations of H. P. Blavatsky's views on Tibet. During his years at Adyar, his scholarship was influenced by theosophical ideas. Thus, he relied on Leadbeater's clairvoyance with regard to the dating of a Tibetan folio: "Psychic researchers may note down the case here related as an interesting document for study, and those interested in this problem will find a good illustration of a chance

Ә Open Access. (c) 2021 Yves Mühlematter and Helmut Zander, published by De Gruyter. (c) BY-NC-ND This work is licensed under the Creative Commons Attribution-NonCommercial-NoDerivatives 4.0 International License. https://doi.org/10.1515/9783110664270-023 
example of clairvoyance" (A Mysterious Manuscript, n.p.). His later tibetological works do not show any particular relation to theosophical ideas.

Richardus, Peter. The Dutch Orientalist Johan van Manen. His Life and Work. Leiden: Kern Institute, 1989; Van Manen, Johan. Annie Besant. Een korte levensschets. Amsterdam: Uitgave van de Theosofische Uitgeversmaatschappij, 1898; . "A Mysterious Manuscript.” The Theosophist, January 1911, available online at: http://www.cwlworld.info/A_MYSTERIOUS_MANUSCRIPT.pdf (13.1.2019). — . A Contribution to the Bibliography of Tibet. Journal \& Proceedings of the Asiatic Society of Bengal, New Series. Vol. XVIII, 1922, No. 8, 445-525 (Published separately, November 16th, 1923). 